\title{
Ancestral Eternity in Alice Walker's The Temple Of My Familiar
}

\author{
Santosh Kumari \\ Associate Professor, Department of English \& Foreign Languages Maharishi Dayanand University, Rohtak, \\ Haryana, India
}

\begin{abstract}
Ancestral eternity in Walker's fiction undeniably opens a gateway to wisdom and cultural connectivity. Manifestations of infinite existence include Supreme Being directing the present generation to live in coordination and harmony. Ancient presence not only helps to resolve complex issues but also constructs a sublime identity where past and present is well assimilated. The concept of ancestry in Walker's fiction thus retains ambivalent relevance of African values and embodies continuous flow of cultural ethos. Ancestral presence in Walker's The Temple of My Familiar operates through the memory of Lissie, the protagonist who travels a world of endlessness, where animals and human beings cohabited in harmony. However, when the world today is torn with cut throat competition, materialism, malice and envy, such ideal living is of utmost importance. This mode of establishing values through ancestral eminence is innovative and also adds aesthetic beauty to presentation.
\end{abstract}

Keywords: African, Ancestral, Eternity, Endlessness, Materialism

Walker's fiction incorporates ancestral figures as central components of community structure. The concept of ancestral presence is so crucial and commanding that the meaning of the text cannot be manifested without the accentuation of the ancestry. African cultural codes are distinctly defined both by the concrete and abstract imagery. The ancestor signifies a singular unit embodied through blurring references of historic existence. Thus ancestral figure is generally perceived as timeless creation representing a complex relationship between past and present. However, the presence of ancestor's position is never explicitly projected. Their distinguished strength is implied through assertive guidance and influence of past. Transcending the boundaries of time and space, these "timeless people" as Tony Morrison stated, "are benevolent, instructive and protective, and they provide a certain kind of wisdom"(343).Walker's novels demonstrate such ancestral entities as directing force towards righteousness. Walker extensively employs ancestral imagery in the process of writing and transforms hidden meaning through heavily laden ancestral values.

\section{Codes Of Cultural Connectivity}

Walker's demonstration of the glorified stature of ancestral figure has always been an ambivalent one. While on one hand, Walker's fiction seems deeply rooted within the conventional strands of African-American culture, her bold condemnation of outdated constraints simultaneously extends her redefined modern view. However, the distinguished presence of the supreme entities of ancestral figure is inexplicitly implied through high admiration of them by the present living character. Ancestral figure is generally perceived as a sublime mystic power intervening in the present operation. Observing the state of high esteem of ancestry in The Temple of My Familiar, Ikenna Dieke stated , "the characters betray a peculiar passion to reconnect with their past...For them, without a principle of continuum of the past merging with the present in a constantly shifting melange, it becomes meaningless to speak of the self'(509). Revealing a very personal account of her exciting view of ancestral presence, Walker depicts:

I gathered up the historical and psychological threads of the life my ancestors lived, and

in the writing of it I felt joy and strength and my own continuity...that wonderful feeling writers get sometimes, not very often, of being with a great many people, ancient spirits, all very happy to see me consulting and acknowledging them and eager to let me know, through the joy of their presence, that indeed, I am not alone (453).

The elevated status of Miss Lissie, a transcendent female figure in The Temple of My Familiar symbolises a high opinion and exciting notion for ancestral presence. Similarly ancestral figure symbolised through Africa in The Color Purple visualises idiosyncrasies of ancestry as Walker dedicates the novel "to the spirit/ without whose existence/ neither this book / nor I / would have been / written" (ii). Ancestry as represented through Miss Lissie in The Temple of My Familiar symbolises cultural, historical and even mythical existence of human race. She is an epitome of the wisdom of past and through her forbearance and experiences of slave trading, she observes herself as a "traveller following the ancient and even pre ancient paths" (366). She is truly an eternal figure and connecting all the three tracks of past, present and the future, she shifts beyond the boundaries of time 
and space. She remembers everything and incorporating past experiences of her deceased parents and slave trading, she becomes a symbol of "race memory"(Dieke 508).

\section{Past: A Reverend Entity}

Abridging the gap between past and present, she symbolises "a concentrated form of energy"(44) and continuous flow of time gathers through her spirit. She is updated with fresh memories of everything. Lissie functions as a reincarnated spirit. Her eyes are brilliant and steady as that of a hawk. Lissie looks even through "drowned" ancient civilizations. Though she admits to Suwelo "I am old now and my brain cells- brain cells are like batteries, you know- are dying, millions of them at a time...I do not 'remember with my brain itself anyway, but with my memory, which is separate somehow, yet contained within. Charged, I feel my brain, is with memory. Yes, as I said, like a battery" (52). Lissie manifests a broad and infinite corporal form and encompasses One Whole of human experience and can recall anything. Her elevated status symbolises the eternity of ancestral character that deems to meet the primary standards of benevolence and generosity. Animals and human beings were both intimate and even the barbarous wild dogs settled down side by side. Lissie remembers, "In those days of which I am speaking, people met other animals in much the same way people today meet each other. You were sharing the same neighbourhood, afterall. You used the same water, You ate the same food, You sometimes found yourself peering out of the same cave waiting for a downpour to stop"(361). Human society along with the animals, their familiars, constituted a sense of mutual trust. Fraternity and earnestness permeated all through their life, and harmony prevailed in the common coexistence. All were amicable and enjoyed solidarity and rejuvenation.

However, by and by greed and lust exclusively in terms of imperial expansion and capitalism devastated human values. Now the relationships are changed and the bonds are immaterial. Man has got so self centred that he can go to any extent to materialize his monetary dreams. Racial conflicts and gender politics unlashed reckless atrocities on the blacks who were treated inferior because of their skin. Walker's novels depict the most horrifying episodes of slave trading and human robbery. Lissie in The Temple of My Familiar is shocked at the stunned situation and says, "of course everything that was once free is different today"(363). Recalling her capture into slavery and hardships on board to the Middle Passage, Miss Lissie undeniably symbolises the pain of losing high cultured status of Africa. She painfully remembers that it was her uncle, who sold her mother and children to white masters so that he may procure money and buy dazzling tinklets for his wife. This tempting bargain instigates her uncle's satanic instinct and he commits the most heinous deal against his own dependent women and children. Lissie's mother begged for mercy but she was kicked aside. Her shrieks failed to melt the heart of white master. Utter dejection and helplessness is horribly disturbing. This episode highlights a world of self centeredness where all bonds of human relationships are snapped off to accumulate more and more material gains. Walker displays great courage as she does not hesitate to put her own community to a rigorous examination and lashing. Women have to silently submit to their own patriarchy that trades them like lifeless lumps. This way Africa seems to have lost the venerated status and ceases to be the embodiment of wisdom and rich heritage. While passing through utmost humiliation, rape, atrocities and hardships of the Middle Passage, Lissie regrets of loosing Africa and claims,

So I am very bitter about my old home, and who can claim. I do not have a

right to be? This is no heresy. I was there. My mother could not tolerate

so much filth and on the seventh day she willed herself to die. The white men

sent in a couple of brutes to drag her out of her heels - one of them held a rag

to his nose as they dragged her - and placed her body on a cart and carry it away.

I envied her. I pitied myself. I did not know how to ask the strangers or even

my sisters and brothers to kill me (65).

Memories are instrumental to create integrity in the world of time. It provides a shield to passing time in defiance of outward hurdles. In The Temple of My Familiar, Walker attempts to relocate the lost self. The prominent character of Lissie symbolises inner identity in the context of exterior social, political and personal life. Walker's rhetorical strategy reveals the complexity of recollective art that helps to weave a pattern of past and present. Lissie as a corporal form of African ancestry ceaselessly walks through time and space. Her infinite physical presence through various forms as human, animals and birds, manifests her ancestral familiarities. She talks about her previous births as a lion, as a bird and as a white male. Incorporating the experiences of her previous lives, Lissie admits that she "swallowed past experiences all her life" (366). She strives to absorb herself into a timeless phenomenon and appears as a transcendent ancestral figure who encompasses the whole of human civilization. She is a repository of collective memory of past and present and communicates Walker's message that by boycotting our tradition and heritage, we cannot march ahead. An interaction between the past and present and regeneration of ancestral wealth is indispensable. Walker seems to insist in developing an ambivalent bond between African culture of the past and the present. Dimensions of democratized world of 
today are explicitly generated through creativity and legacy of blacks. Past and present are to be intertwined so that continuous flow of ever growing human civilization on this planet may go on.

Another aspect of ancestral eternity in The Temple of My Familiar, is projected through a myth that invented history of human civilization. Ancestry for Walker is eternal human experience. It also reflects an individual quest for identity and to recapture affinity with the present world. This communion between ancestral past and present milieu works through various channels including tribal and cultural ethos. Lissie serves a central symbol and traces human life to mythical dimensions with both its recession and growth. Fanny and her ex-husband Suwelo, a middle class academician find their authentic self by pursuing Lissie's message. Their journey to meet their African kinfolk becomes possible when they penetrate into ancestral inheritance through Lissie's dreams and archetypal memories. They could have lived better in bird shape houses and followed gospel of equality and human love. But it could be possible with ancient mode of value based practical life where animals and humans coexisted in perfect balance. Ancestral eternity in the novel is also reflected through culture oriented art of conversation and language that helps to establish an atmosphere of social and emotional relatedness and also reveals a spirit of eternal truth and beauty. Walker as an artist deliberately attempts to give a concrete form to the vision of supreme functioning that operates through the chain of universal existence. The novelist seems preoccupied with the belief that human soul is a part of the infinite. She plunges deep into the obscure regions of eternal universe and enables the reader to penetrate into eternal past which is greatly related to the vitality of present. The novel synthesises various patterns of life so that a state of self healing totality may be recaptured.

\section{References}

[1]. Dieke, Ikenna. "Towards A Monistic Idealism: The Thematics of Alice Walker's The Temple of My Familair" African- American Review 26.3 (1992): 507-14

[2]. Morrison, Tony. "Rootedness: The Ancestor As Foundation." Black Women Writers(1950-1980): A Critical Evaluation. Ed Mari Evans . New York : Double Day, 1984. 339-45

[3]. Walker, Alice. The Color Purple. New York : Pocket, 1982.

[4]. Walker, Alice. The Temple of My Familiar. New York : Pocket, 1989.

[5]. Walker, Alice "Writing The Color Purple." Black Women Writers(1950-1980): A Critical Evaluation. Ed Mari Evans . New York: Double Day, 1984. 453-56 